\title{
DEVELOPMENT OF MODULE OF LEARNING GEOMETRY BASED ON VAN HIELE THEORY
}

\author{
Deshinta P.A.D. Argaswari ${ }^{1)}$ \\ ${ }^{1}$ Sampoerna University, Jakarta \\ Email:
}

\begin{abstract}
The aim of this research was to develop a teaching and learning module using Van Hiele theories for quadrilateral topics in grade VII students in middle school, which is valid, practical, and effective. Literatures explain that nowadays the students over generalize the concept of geometry without further understanding about the concept of geometry and the skills of proving and reasoning that geometry field try to improved. The method used was research and development with modification of Borg and Gall and Plump method. The initial investigation stage result stated that only $22.6 \%$ of students reached level 2 informal deduction, $35.5 \%$ students reached level 1 analysis and the rest of students were still in level 0 visualization. In order to solve this problem, the design and realization stages developed a module which was written based on phase of learning geometry. Next, the module was verified through trial test in a class of students grade VII in order to get data of validity and effectivity. Lastly, the module was tested through experimental research by comparing experimental and control class. The module was valid based on validator review. The module was effective because it can increase students geometry thinking level by $48 \%$. The nonparametric test using K-S and Man Whitney show that the result of level of geometry thinking in experimental class was better than the control class. Overall result state that the module valid and effective.
\end{abstract}

Keywords: Geometry, Quadrilateral, Van Hiele, Research and Development Method, Kolmogrov Smirnov Nonparamametric test

\section{PENDAHULUAN}

Students at secondary level are suppose to have a higher understanding that geometry more than a shape. NCTM (in Bieber 2013) stated that students at seconday are suppose to have proving and reasoning skills in geometry. The study of geometry done by Clements and Battista (1992) already indicated that students in secondary level are supposed to have deduction skills in order to understand geometry at least the informal one. Based on Van Hiele level of thinking geometry, students in junior high schools can be divided into three level of thinking: Level 0 Visualization, Level 1 Analysis, and Level 2 Informal Deduction (Crowley, 1987). Mistretta (2000) link the students' geometry thinking level with Van Hiele theories, his study come to conculsion that students at secondary level are supposed to be in Level 2 Informal Deduction.

The unmatch of students thinking level to the geometry topics impacted to the misconceptions and difficulties of students in learning geometry. Bieber (2013) in his research found out that mostly students has a misconceptions of geometry shapes such us instantly put a right angle without analysis its properties. Okazaki dan Fujita (2007) found that students easily generalized the concept of geometry. In quadrilateral topic, students tend to memorize the properties rather than understanding the properties and its implications. Another research of Fujita and Jones (2007) stated that only $20 \%$ of students reach informal deduction level. 
In theories of Van Hiele geometry thinking level, the level of geometry thinking can be increased using instruction. The instruction is given based on Five Phase of Learning Geometry (Erez \& Yerushalmy, 2006). This phase of learning is designed to help teacher design a teaching and learning activities in order to increase students' thinking. In this case, this phase can be designed to help all students reach level 1 Analysis. After that, this phase also can be done to help students reach level 2 Informal Deduction. Other than the design of activities, this phase of learning needs teacher's intervention in facilitating the learning activities. It is happened because the increasing of level of thinking cannot be done naturally, meaning that teaching and learning geometry need to be done using activities designed based on five phase of learning geometry and teacher facilitation (Burger, 1986).

This 5 phase of learning geometry is arranged systematically as inquiry phase, free orientation phase, explication phase, direct orientation, and integration phase. The teaching and learning activities is arranged based on these phase and should be arranged systematically. In other hand, students' ability of learning is variety. It means that the speed of learning will be different. Therefore, these phase of learning need to be written in module, so students are able to study individually based on their level of thinking (Daryanto, 2002). In fact, module which contain this phase of level is hard to find in Indonesia. Pre-survey shows that commonly the quadrilateral topic is written with order such as definition of quadrilateral, properties of quadrilateral, area and perimeter of quadrilateral, and evaluation. Teacher also follow the order written in book of reference. Commonly, the book of reference does not provide activities to facilitate students to think deductively.

The preliminary investigation of this research also shows that students' geometry thinking level is vary from Level 0 to 2 in Grade VII SMP N 1 Selogiri. The students from Level 0 and Level 1 are suppose to helped improving their skills. In order to improved the level, instruction should be changed (Fujita and Jones, 2007). The instruction is based on the teacher references such us book and module (Feza, 2005). Therefore in order to improved the level, the references should be modified or developed based on the literature review or adequate theories.

This research will explain the development of module based on Van Hiele theorie and the effectiveness of the module. The module is supposed to be effective in helping students improved their thinking level. Hence, the research question of this research is the effectiveness of module of learning geometry that developed based on Van Hiele theories. The detail of theories and the effectiveness criteria is explained on literature review sub

Van Hiele theories of geometry consist of exist level, properties of level, and movemenet from one to another level. Exist of level shows the hierarcy of geometry thinking level (Burger, 1986). It consist of 5 level but the students' thinking level at seconday is vary from Level 0 to Level 2 (Fujita and Jones, 2007). 
- Level 0: Visualization: Students in this level are able to give name for selected quadrilateral but they are not able to give correct reason. They likely say "because it looks a like". Students also able to draw a quadrilateral based on its name. The drawing is not detil means there is no sign of similar sides or angles or others

- Level 1:Analysis: Students in this level are able to link the figure of quadrilateral with its properties. They are able to state the properties or analyze quadrilateral based on properties given. But, students in this level could not show the relationship of quadrilateral.

- Level 2: Informal Deduction: Students in this level are able to show how one class of quadrilateral has relation to others class of quadrilateral. Students are able to give reason based on properties of quadrilateral. But, students could not give a reason formally and systematically as proofing

In order to move from one to another level, teh teaching and learning geometry should be consist of The Five Phase of Learning Geometry (Burger 1986, Clements \& Battista, 1992). The 5 phase of learning geometry are (1) inquiry, (2) free orientation, (3) explication, (4) direct orientation, (5) integration.

The module that has been developed will tested through experimental research. The purpose of this experimental research is to know the effectivity of modul. Based on Nieveen (in Sunardi, 2005), the product is effective if the product are able to satisfied the purpose of research (Kemp et al in Sunardi, 2005). Since the purpose of this research is to improved students' geometry thinking level so the module is effective if (1) there is an improvement of geometry thinking level, and (2) the statistic test shows that students' geometry thinking level in experiment class is better than control class. The improvement can be seen from the data of pre and post test. The statistic test will use non-parametric test since the data is distributed in ordinal data. Sugiyono (2009) and Sheskin (2003) said that non-parametric test with ordinal data in order to test the effectiveness can be done by Kolmogorov Smirnov test. Firstly, the pre test data from each class will tested to know its homogenity. Secondly, comparison of pre test data from both classes is tested to know that both data has similar geometry thinking level. Lastly, post test data from both class tested to know the effectiveness of treatment in experiment

\section{METODE PENELITIAN}

This methods of this research is Research and Development (R\&D) continued with experiment. $R \& D$ is a method of developing a product through research (Sukmadinata, 2005). The methods of developing the product is modified from Plomp method (1997) and Borg \& Gall method (Sukmadinata, 2005) as follow:

Preliminary Investigation

Preliminary investigation is done by literature review about geometry concept especially quadrilateral and Van Hiele theory. At the same time, researcher collect data of students' level of geometry thinking. Other than that, students' references and books is analyzed to get the preliminary data. 
Design

Product is designed based on the findings and result analysis on preliminary investigation stage. Through the investigation, it can be seen the students' need of the module design.

Realization

The module is written based on the design proposed from previous stage. At this time, draft module is completely written and ready to be tested.

Test, Evaluation, and Revision

The draft of module is tested in 4 sub stages: validator of media and content, one or two students, a small group of students, and a class. On each sub stages, the module is evaluated through the suggestions and comments from subject. Revision is done referring to the evaluations given. Therefore, at the end of this stage, the final draft module is ready.

The pretest and posttest is given to see the improvement of level. The test instrument is adapted from Okazaki and Fujita (2007) and then validated by the expertise. Other than that, the instrument is tested to 30 students and the reliability number is 0.8 .

FGD

The final draft module is discussed through focus group discussion. The member of the discussion are mathematics teachers.

Experiment

After FGD, the module is experimented by choosing two classes named control class and experiment class. Before and after treatment, both class is tested regarding to their geometry level of thinking. The data is analyzed using Kolmogorov-Smirnov (K-S) test because the geometry thinking level is explained in ordinal data which is classified as nonparametric statistical data.

\section{HASIL PENELITIAN DAN PEMBAHASAN}

Through the research and development method, the product that is module is tested based on its validity. After that though the experiment, the effectiveness of module is also tested.

\subsection{Preliminary Investigation}

There are several aspects that investigated though this level. The students' geometry level of thinking is $34 \%$ stay on Level $0,56 \%$ on Level 1 , and the rest which is $10 \%$ stay on Level 2 . This result indicated that the geometry thinking level is not adequate. The next investigation is done by analyzing students' book and teaching references. The quadrilateral topic is design by giving definition, properties, and questions. In other hand, the literature review of Van Hiele theories discuss about phase of learning geometry such us inquiry, free orientation, explication, direct orientation, and integration. The unmatched theories and concept of literature review about geometry theory with the students' book reference leads to conclusion that students' geometry thinking level can be improved by design a module of learning geometry based on Van Hiele theories. 


\subsection{Design}

Based on the preliminary investigation, the need of designing a module is implemented by design a module based on Van Hiele theories. Since the phase of learning is stated already on the Van Hiele theories, the design of module will arranged as follow (1) about quadrilateral, (2) preface, (3) Learning Activity and Questions refer to the 5 phase of learning geometry, (4) summary, (5) test. The design of the module is refer to the phase of learning geometry with the detail can be seen on Table 1 .

Table 1. The Phase of Learning Geometry

\begin{tabular}{|c|c|c|}
\hline & Unit 1 & Unit 2 \\
\hline $\begin{array}{l}\text { Learning } \\
\text { Objectives }\end{array}$ & $\begin{array}{l}\text { Students are able to understand the } \\
\text { definition and properties of } \\
\text { quadrilateral. }\end{array}$ & $\begin{array}{l}\text { Students are able to apply the properties of } \\
\text { quadrilateral into relationship among } \\
\text { quadrilateral. }\end{array}$ \\
\hline Inquiry & $\begin{array}{l}\text { Identify quadrilateral shape in daily } \\
\text { life. }\end{array}$ & $\begin{array}{l}\text { Identify the change of sides and angles in } \\
\text { quadrilateral }\end{array}$ \\
\hline Free Orientation & $\begin{array}{l}\text { Classify quadrilateral into six group } \\
\text { of quadrilateral. }\end{array}$ & Explore the changing shape of quadrilateral. \\
\hline Explication & $\begin{array}{l}\text { Identify the properties of } \\
\text { quadrilateral. }\end{array}$ & $\begin{array}{l}\text { Explain the relationship of quadrilateral } \\
\text { shapes. }\end{array}$ \\
\hline $\begin{array}{l}\text { Direct } \\
\text { Orientation }\end{array}$ & Practice problems. & Practice problems. \\
\hline Integration & $\begin{array}{l}\text { Summarize the definition and } \\
\text { properties of quadrilateral }\end{array}$ & $\begin{array}{l}\text { Summarize the relationship of quadrilateral by } \\
\text { making diagram. }\end{array}$ \\
\hline
\end{tabular}

\subsection{Realization}

The draft module is completely written based on design from previous stage. The module is written with reference to book in tittle Contextual Teaching and Learning Mathematics (Wintarti et al, 2008), journal in tittle Elementary Geometry for College Students (Koberlain, 2011), module in tittle Pembelajaran Matematika SMP di LPTK (USAID, 2014), and Monograph of Van Hiele theories (Fuys et al, 1988). The general review of the modul can be seen on Table 2.

Table 2. Activity of Unit 1

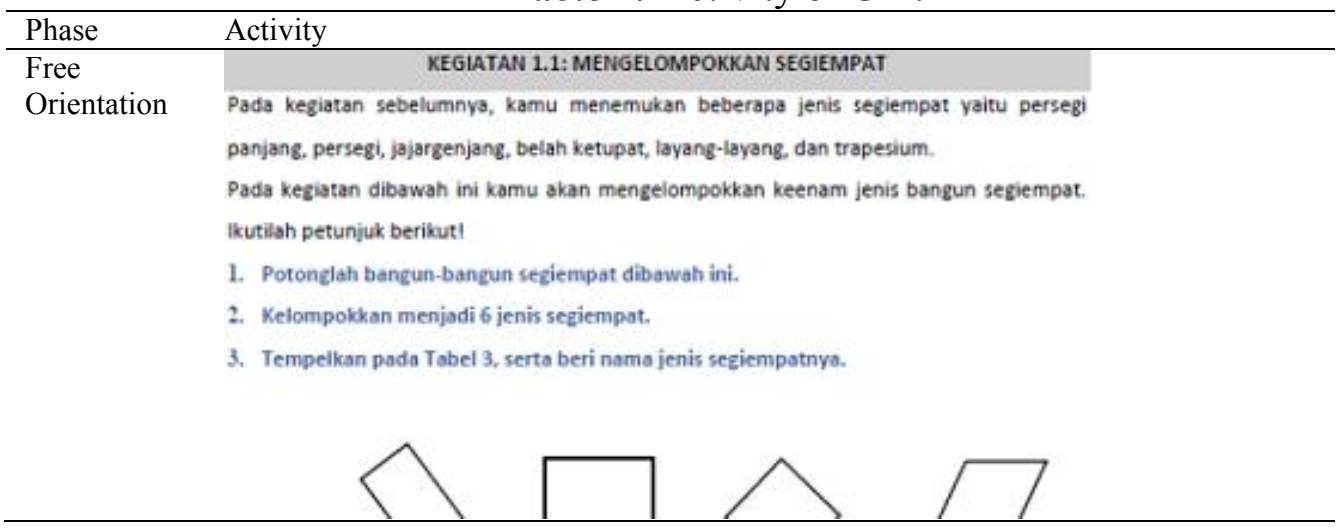




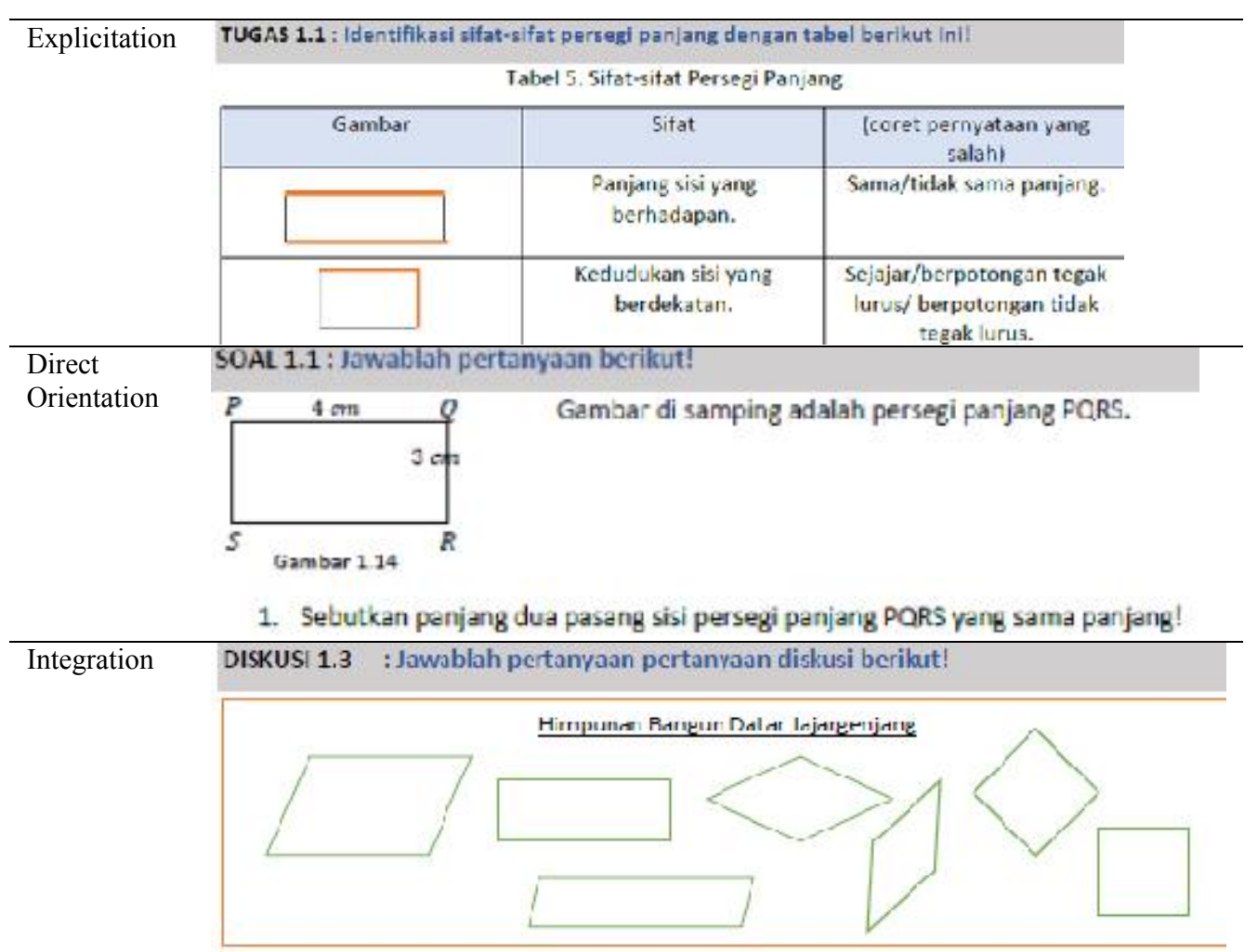

1. "Jajargenjang adalah segiempat yang ranjang sisi berhadaparnya sama". Apakah perrvataan di atas cukup untuk mengફambarkan ıalargenıøng? Jelaskan!

\subsection{Test, Evaluation, and Revision}

Draft module is revised on and on based on the evaluation of each sub stages. The first sub stages is done by 6 validators of media and contents coming from lecturer and mathematics expertise. In general, the part of module that need to be revised is the word used in definition and the consistency of symbols used. The second sub stages is done by randomly choose 2 students. Those students read the module and give feedback by giving sign to the part that difficult to understand. Mostly feedback is given to the word that unfamiliar for the students. The third sub stages is done by held a microteaching with 5 students. This microteaching indicated the instruction that is unclear for students. At the end of the stage, module is tested in trial class: Grade VII H. Based on the pre and posttest, students' geometry thinking level is increased by $48 \%$. Table 3 shows the detail changing level.

Table 3. The Changing of Geometry Thinking Level for Trial Class

\begin{tabular}{|c|c|c|c|c|c|c|c|c|}
\hline \multirow{3}{*}{ Level } & \multicolumn{6}{|c|}{ Changing } & \multirow{2}{*}{\multicolumn{2}{|c|}{ Total }} \\
\hline & \multicolumn{2}{|c|}{ No change } & \multicolumn{2}{|c|}{$\mathrm{Up}$} & \multicolumn{2}{|c|}{ Down } & & \\
\hline & f & $\%$ & f & $\%$ & F & $\%$ & $\mathrm{~F}$ & $\%$ \\
\hline VII H & & & & & & & & \\
\hline 0 & 2 & 100,00 & 0 & 0,00 & 0 & 0,00 & 2 & 8,00 \\
\hline
\end{tabular}




\begin{tabular}{lllllllll}
\hline 1 & 6 & 54,55 & 2 & 18,18 & 3 & 27,27 & 11 & 44,00 \\
2 & 2 & 16,67 & 10 & 83,33 & 0 & 0,00 & 12 & 48,00 \\
Total & 10 & 40,00 & 12 & 48,00 & 3 & 12,00 & 25 & 100,00 \\
\hline
\end{tabular}

\section{5. $F G D$}

FGD is held with 2 mathematics teacher and 1 expertise. The discussion is focus on the module and its implementation. Some revision is done based on the discussion. In general, the revision is done by changing the format of questions such us no redundant words.

\subsection{Experiment}

After FGD, the module is experimented by choosing two classes named control class and experiment class. Before and after treatment, both class is tested regarding to their geometry level of thinking. On experiment class, there are several changing on the geometry thinking level of students. The pretest result shows that $41.9 \%$ students on Level $0,35.5 \%$ on Level 1 , and $22.6 \%$ on Level 2 . After treatment, the posttest result shows that $0 \%$ students on Level 0,33.3\% students on Level 1, and $66.7 \%$ students already on Level 2. By comparing pre and posttest data, it can be seen that $70 \%$ students improved their level with 7 students to Level 1 and 14 students to Level 2. The data also shows that $26.67 \%$ students stay on their level with 2 students at Level 1 and 6 students at Level 2. There is also decreasing level. It is $3.33 \%$ with 1 students decrease his level from Level 2 to 1 . The detail of the changing can be seen on Table 4 .

Table 4. The Changing of Geometry Thinking Level for Experiment Class

\begin{tabular}{|c|c|c|c|c|c|c|c|c|}
\hline \multirow{3}{*}{ Level } & \multicolumn{6}{|c|}{ Changing } & \multirow{2}{*}{\multicolumn{2}{|c|}{ Total }} \\
\hline & \multicolumn{2}{|c|}{ No change } & \multicolumn{2}{|l|}{ Up } & \multicolumn{2}{|c|}{ Down } & & \\
\hline & $\mathrm{f}$ & $\%$ & $\mathrm{f}$ & $\%$ & $\mathrm{f}$ & $\%$ & $\mathrm{~F}$ & $\%$ \\
\hline VII D & & & & & & & & \\
\hline 0 & 0 & 0,00 & 0 & 0,00 & 0 & 0,00 & 0 & 0,00 \\
\hline 1 & 2 & 20,00 & 7 & 70,00 & 1 & 10,00 & 10 & 33,33 \\
\hline 2 & 6 & 30,00 & 14 & 70,00 & 0 & 0,00 & 20 & 66,67 \\
\hline Total & 8 & 26,67 & 21 & 70,00 & 1 & 3,33 & 30 & 100,00 \\
\hline
\end{tabular}

In order to test module effectiveness, the pre-posttest data from experiment class is compared to control class. Before treatment, the pretest data from both control and experiment class is tested statistically. First each data is homogeneity tested and then both data tested together through nonparametric test. The purpose of this statistic test is to make sure that the geometry thinking level of both class is similar. The statistic test uses non-parametric test named Kolmogorov-Sminorv (K-S test). Those tests is chosen because the data of this research is ordinal data.

The hypothesis of statistic test is " $H_{0}$ : the students' geometry thinking level of both class is similar".

Table 5. K-S Test Computation for Pretest

\begin{tabular}{llllll}
\hline & & & Cum $\%$ & Cum \% & \\
Level & Experiment & Control & Experiment & Control & Different \\
\hline 2 & 7 & 6 & 0,23 & 0,19 & 0,03 \\
1 & 11 & 11 & 0,58 & 0,55 & 0,03 \\
0 & 13 & 14 & 1,00 & 1,00 & 0,00 \\
\hline
\end{tabular}




\begin{tabular}{lllll} 
Total & 31 & 31 & $\mathrm{M}$ & 0,03 \\
\hline
\end{tabular}

The K-S test of homogeneity shows that value of $\mathrm{M}$ that is 0.03 is smaller than $\mathrm{M}$ table with $5 \%$ confidence interval that is 0.35 . Table 5 shows the detail calculation. It indicated that the value of $\mathrm{M}$ is not in sets of Critical Region $(\mathrm{CR}=$ $\{\mathrm{M} \mid \mathrm{M}>0.35\}$ ). Therefore the null hypothesis is accepted and it summarize that both class has similar level of geometry thinking.

After both classes are statistically tested, treatment is given to experiment class using module that have been prepared from previous research. At the end of topics, geometric thinking level of both classes are tested through posttest.

Table 6. K-S Test Computation for Post test

\begin{tabular}{llllll}
\hline & & & Cum $\%$ & Cum $\%$ & \\
Level & Experiment & Control & Experiment & Control & Different \\
\hline 2 & 20 & 8 & 0,67 & 0,28 & 0,39 \\
1 & 10 & 18 & 1,00 & 0,90 & 0,10 \\
0 & 0 & 3 & 1,00 & 1,00 & 0,00 \\
\hline Total & 30 & 29 & & M & 0,39 \\
\hline
\end{tabular}

The result of the computation of K-S test shows that the value of $M$ that is 0.39 is greater than $\mathrm{M}$ table which use $5 \%$ confidence interval that is 0.32 . It indicated that $\mathrm{M}$ is in the set of critical region $(\mathrm{DK}=\{\mathrm{M} \mid \mathrm{M}>0.32\})$. The detail computation is shown on Table 6 . Therefore, the summary of this result stated that "the geometry thinking level of students on experiment class is better than control class students."

The statistic test through non parametric K-S test shows that there is a significant change of geometry thinking level. It indicated that the module of learning geometry that has been developed is able to help students increasing their geometry thinking level. There are two criteria that set in order to decide how effective the module. The first criteria stated that module is effective if more than $30 \%$ students in trial class improved their geometry thinking level. The test on trial class as shown on Table 4.4 shows that $48 \%$ students improved their geometry skills. Therefore the first criteria is satisfied. The second criteria stated that module is effective if there is significant improvement on experiment class. The significance is taken from result of K-S test and as shown on the result of K-S test on Table 4.8, it indicated that there is a significant change. Therefore first and second criteria is satisfied and it can be stated that module of learning geometry is effective to improve students' geometry thinking level

\section{SIMPULAN DAN SARAN}

\section{Simpulan}

After the stages of research and development method done, the module of learning geometry based on Van Hiele theories is developed with valid, practical, and effective. Based on validation of 6 expertises, the module is valid which is 
contains the phases of learning of geometry based on Van Hiele theories and able to meet the required learning objectives. After several tests from the individual test to the whole class test, the module is practical to increase the students geometry thinking level. Lastly, the module is effective to reach the purpose of this research which is to develop the proving and reasoning skills of students indicated by students reaching Level 2 at Van Hiele level. It can be seen from result and discussion, through $\mathrm{K}-\mathrm{S}$ test the module is effective

\section{Saran}

We would like to thank Dr. Ikrar Pramudya and Dr. Mardiyana M.Si. who kindly become validator for validation sheets. We also would like to thank Desyarti Safarini S.Pd, M.Si, Dhitta Puti Sarasvati, M.Ed, Budi Huang, Sutopo S.Pd, M.Pd, Agus Kristanto, Supriyadi Wibowo S.Si, M.Si, who kindly become our validator and give suggestion for module revision. We would like to thank Tulus Sarnyoto, S.Pd, and Tri Murniati, S.Pd, who kindly support the realization of this research and kindly help us connect to students. Finally, we would like to thank SMP N 1 Selogiri, Universitas Sebelas Maret, and Sampoerna University, who support us doing this research and development

\section{DAFTAR PUSTAKA}

Bieber, C., Tuna, A., \& Korkmaz, S. (2013). The Mistakes and the Misconceptions of The Eighth Grade Students On The Subject of Angles. European Journal of Science and Mathematics Education, 1 (2), 50-59. Diakses dari scimath.net/articles/12/122.pdf

Clements, D. H., \& Battista, M. T. (1992). Geometry and Spatial Reasoning. Diakses dari http://psycnet.apa.org/psycinfo/1992-97586-018

Crowley, M. L. (1987). The Van Hiele Model of The Develeopment Geoemtric Thought. Yearbook of The National Council of Teachers of Mathematics. Accessed from http://www.csmate.colostate.edu/docs/math/mathactivities /june2007/The\%20van\%20Hiele\%20Model\%20of\%20the\%20Developm ent $\% 20$ of $\% 20$ Geometric $\% 20$ Thought.pdf

Mistretta, R M. (2000). Enhancing Geometric Reasoning. Adolescence, 35 (138), 365-379. San Diegeo: Libra Publisher

Okazaki, M. \& Fujita, T. (2007) Prototype phenomena dan cognitive path in the understanding of the inclusion relation between quadrilateral in Japan and Scotland. Dalam Ho Woo dkk. Proceedings of The 31st Conference ot The International Group for The Psychology of Mathematics Education, 4. Korea: The Korea Soeciety of Educational Studies in Mathematics.

Fujita, T. \& Jones, K. (2007). Learners' Understanding of Definition and Hierarcial Classification of Quadrilateral: Towards A Theoreitical Framing. Research in Mathematics Education, 9 (1\&2), 3-20. Accessed from soton.ac.uk/49731/1/Fujita_Jones_RME_vo19_2007.pdf http://eprints.

Erez, M. M. \& Yerushalmy, M. (2006). "If You Can Turn a Rectangle into a 
Square, You Can Turn a Square into a Rectangle..." Young Students Experience the Dragging Tool. International Journal of Computers for Mathematical Learning, 11(3), 271-299

Burger, W. F. (1986). Characterizing the Van Hiele levels of developmetn in geometry. Journal for Research in Mathematics Education, 17 (1), 31-48. Accessed from http://math.buffalostate.edu/ MED595/Casestudy1.pdf

Daryanto. (2002). Menyusun Modul Bahan Ajar untuk Persiapan Guru dalam Mengajar. Yogyakarta: Gava Media

Feza, N. (2005). Assessment Standards, Van Hiele Levels, and Grade Seven Learners' Understanding of Geometry. Pythagoras, 62, 36-47.

Sunardi. (2005). Pengembangan Model Pembelajaran Geometri Berbasis Teori Van Hiele. Disertasi UNESA

Sugiyono. (2009). Statistik Non Parametris Untuk Penelitian. Bandung: Alfabeta.

Sheskin, D. J. (2003). Handbook of Parametric and Nonparametric Statistical Procedures. America: Chapman \& Hall/CRC.

Sukmadinata, N. S. (2005). Metode Penelitian Pendidikan. Bandung: PT Remaja Rosda Karya

Wintarti, A., Rahaju, E. B., Sulaiman, R., Yakob, C., \& Kusrini. (2008). Contextual Teaching and Learning Matematika: Sekolah Menengah Pertama/ Madrasah Tsanawiyah Kelas VII Edisi 4. Jakarta: Departemen Pendidikan Nasional.

Koberlein, A. (2011). Elementary Geometry for College Students. Canada: Nelson Education, Ltd.

Fuys, D., Geddes, D., \& Tischler, R. (1988). The Van Hiele Model of Thinking in Geometry Among Adolescents. Monograph, i-196. Accessed from http://www.jstor.org/ stable/749957 